\title{
Quality of recovery assessment of day case and multiday stay patients undergoing elective laparoscopic cholecystectomy
}

\author{
Matthew Campbell ${ }^{1}$ (D), Daniel Ng${ }^{1}$ (D), Batool Albatat ${ }^{1}$ (D), Darren Lowen²(D), David Bird ${ }^{1}$ (D), Russell $\operatorname{Hodgson}^{1}$ (D) \\ ${ }^{1}$ Clinic of General Surgery, Northern Health Hospital, Epping, Australia \\ ${ }^{2}$ Clinic of Anaesthetics, Northern Health Hospital, Epping, Australia
}

\begin{abstract}
Objective: Many laparoscopic cholecystectomy operations are performed with at least overnight admission. Current research shows that laparoscopic cholecystectomy is safe and feasible to do as a day case. Patient centred outcomes are less well understood.

Material and Methods: Elective laparoscopic cholecystectomy patients at a single metropolitan hospital in Melbourne, Australia were surveyed 24 hours after surgery using the 15-question Quality of Recovery (QoR-15) survey. A comparison was made between day case surgeries and multi-day surgeries.

Results: One hundred and eight patients were recruited consisting of 34 day case and 74 multi-day patients. Patient groups did not differ in terms of age, sex or postoperative morbidity. The multi-day group had a higher proportion of comorbid patients ( $p$-value $=0.03$ ). There was no significant difference in overall QoR-15 score between the two groups, although there was an observed trend towards a higher score in the day case group (132.0 vs $127.9, p=0.147)$. QoR-15 individual question results showed that day cases rated significantly better for sleep quality and for less feelings of anxiety or worry. The differences narrowed when comparing patient groups as they were booked (intention-to-treat). There were no identified sub-groups that had a significantly higher score if admitted multi-day.
\end{abstract}

Conclusion: Quality of recovery following day case laparoscopic cholecystectomy is just as good, if not better, than multi-day cases. Laparoscopic cholecystectomy as a day case is both safe and economically superior to multi-day management. This gives further weight to current recommendations suggesting that the majority of laparoscopic cholecystectomy operations could be performed as day cases.

Keywords: Laparoscopic cholecystectomy, gallstones, day case, quality of recovery

Cite this article as: Campbell $\mathrm{M}, \mathrm{Ng} \mathrm{D}$, Albatat $\mathrm{B}$, Lowen $\mathrm{D}$ Bird D, Hodgson R. Quality of recovery assessment of day case and multiday stay patients undergoing elective laparoscopic cholecystectomy. Turk J Surg 2021; 37 (4): 355-362

Corresponding Author

Russell Hodgson

E-mail: russell.hodgson@nh.org.au

Received: 29.07 .2021

Accepted: 06.10 .202

Available Online Date: 31.12 .202

(- Copyright 2021 by Turkish Surgical Society Available online at www.turkjsurg.com

DOI: 10.47717/turkjsurg.2021.5451

\section{INTRODUCTION}

There is an increasing push for appropriate patients to have laparoscopic cholecystectomy operations performed as day cases. In Australia, the common post-operative management for laparoscopic cholecystectomy still appears to be at least overnight stay with almost all higher volume surgeons having patients with a median stay of at least one day according to Medicare data (1). This has become a major target of healthcare systems such as in the United Kingdom, with the British Association of Day Surgery recommending that approximately $60 \%$ of laparoscopic cholecystectomy operations be performed as day cases (2). There are, however, still concerns from surgeons as to the feasibility and acceptability of day case laparoscopic cholecystectomy with post-operative pain perceived as the major issue (2-4)

Day case laparoscopic cholecystectomy has also been shown to have a similar rate of adverse outcomes when compared to multi-day stay patients $(5,6)$. The potential health economic effects could be important with financial benefits shown to be significant $(7,8)$. The choice to keep a patient in overnight is both for a perception of improved patient safety and quality of patient recovery; however, there is little research into the effectiveness of day case surgery in terms of patient satisfaction or quality of recovery. What research has been done, usually through patient satisfaction surveys, suggests that day case surgeries are well received by patients, with 
satisfaction ratings just as high as those for admitted patients (2,9). Quality of Recovery - 15 (QoR-15) has been extensively validated and shown to be a reliable measure in surgical settings of patient's quality of recovery, not just pain scores, in a wide range of surgery including laparoscopy and day case surgery (10-12).

This study aimed to evaluate the quality of recovery of patients undergoing elective laparoscopic cholecystectomy in an unadulterated practice in an Australian metropolitan hospital. A superior or non-inferior outcome could help to prompt surgeons to consider day case laparoscopic cholecystectomy as standard, with improvements in patient outcomes and health economics.

\section{MATERIAL and METHODS}

\section{Study Design}

The study was performed at a single centre in Melbourne, Australia. All patients that underwent elective laparoscopic cholecystectomy between August 2018 and December 2018 were assessed for inclusion in the study. Exclusion criteria included age $<18$ years or non-proficient in English language as assessed by requiring an interpreter for consent. Twenty-four hours after surgery, patients were contacted via telephone and verbally consented to take part in the study. Consented patients were administered QoR-15 (Table 1) with scores recorded. In order to keep the answer responses standard, the patients were con- tacted via telephone regardless of their status as an inpatient or outpatient at the time of the questionnaire. Patient notes were reviewed for demographics, comorbidities and surgical details. 30 days post-operatively, patient notes were interrogated for eventual length of stay and morbidity.

Whilst this study did not record specific techniques during the operation, the standard laparoscopic cholecystectomy approach performed at this institution is a 4 port "American" style cholecystectomy with routine intra-operative cholangiogram. Routine post-operative analgesia included recovery room paracetamol, ibuprofen and fentanyl titrated to effect. Ward and discharge analgesia included paracetamol, ibuprofen and oxycodone as required. Surgeons and anaesthetists were not informed of the conduct of this study so as to not change normal behaviour.

\section{Sample Size and Recruitment}

Sample size was calculated assuming a 10\% improvement in score with a standard deviation of 15 , a probability of a type 1 error of 0.05 , and a power of $80 \%$. Based on previous numbers at the study centre, a ratio of 1:3 weighted on overnight stay patients was estimated. The sample size with these parameters was 96 patients, with 24 in the day case group and 72 in the overnight group. Patients were recruited by several investigators and numbers were tallied at the end of each week, with accrual ending when numbers had been reached in both groups.

\section{Table 1. QoR-15 questionnaire}

\section{Part A}

Scored $0-10$ where $0=$ none of the time (feeling terrible) and $10=$ all of the time (feeling excellent)

Consider how have you been feeling in the last 24 hours?

1. Are you able to breathe easily?

2. Have you been able to enjoy food?

3. Do you feel rested?

4. Have you had a good sleep?

5. Have you been able to look after personal toilet and hygiene unaided?

6. Are you able to communicate with family or friends?

7. Have you gotten enough support from hospital doctors and nurses?

8. Have you been able to return to work or usual home activities?

9. Are you feeling comfortable and in control?

10. Do you have a feeling of general well-being?

\section{Part B}

Scored 10 to 0 , where $10=$ none of the time (excellent) and $0=$ all of the time (terrible)

Have you had any of the following in the last 24 hours?

11. Moderate pain?

12. Severe pain?

13. Nausea or vomiting?

14. Feeling worried or anxious?

15. Feeling sad or depressed? 


\section{Statistical Analysis}

Statistical analysis, using SPSS (IBM, Armonk, USA), included one-way ANOVA to compare differences in scores for individual questions and total score in the QoR-15. Comparisons of categorical data were compared using Chi-Square or Fisher's Exact Test. Student's T test was used to analyse continuous data. Statistical significance was set at a p-value of 0.05 for all analysis. Ethical and governance approval was gained from the Northern Health Office of Research and Governance (ALR 16.2018).

\section{RESULTS}

One hundred and eight patients were included in the study, of which 34 were treated as day cases and 74 were admitted as multi-day stay cases. Total QoR-15 scores were compared depending upon length of stay (Figure 1). Cohort numbers for length of stay of more than one day for individual days (other than day 1) were too small to perform analysis on and thus grouped as multi-day stay patients. Demographics and pre-operative data are shown in Table 2. In particular there was a significantly increased number of patients with serious co-morbidities in the multi-day group (14/74 vs $1 / 34, p=0.034)$. No patients lived more than $100 \mathrm{~km}$ from the hospital. There were no operations that required conversion to open procedures and no mortality during the study period.

\section{Quality of Recovery}

Table 3 demonstrates the mean score for each question of the QoR-15 (Table 1) comparing day case and multi-day cases. There was a slight observed increase in scores in the day case group, however this was not statistically significant (132.0 vs 127.9, $\mathrm{p}=$ 0.147). There were two individual question scores that demon- strated statistical significance, both scoring higher in day case: Question 4 (regarding having a good sleep) 7.4 vs $5.9(p=0.013)$; and Question 14 (regarding anxiety and worry) 9.6 vs 9.2 (p- 0.02).

\section{Intention to Treat Analysis}

Patients ' feelings of recovery may relate to preconceived ideas regarding length of stay, thus intention to treat analysis (based on whether the patient was booked as a day case or multi-day stay) was also performed (Table 4). The overall score comparing day case booked patients to multi-day was not significant (130.2 vs 128.8, $p=0.631)$. Question 14 again showed a higher mean score in the day case group (9.8 vs 9.2, $p=0.043$ ).

\section{Factor Subgroups}

Subgroups of the patients were analysed for identification of any particular factors that may indicate appropriateness for overnight admission (Table 5). There was no significant difference between scores for patients with co-morbidities, patients undergoing an additional procedure, or whether the operation was performed on an AM or PM list, although interestingly there was a trend towards higher scores in PM list patients that were managed as day cases (134.5 vs 127.7, $p=0.173$ )

\section{DISCUSSION}

The argument over day case laparoscopic cholecystectomy has typically been waged over patient safety versus health economic implications. The safety of day case laparoscopic cholecystectomy has been confirmed in terms of postoperative complications, mortality and readmissions, with studies demonstrating day case patients having similar rates of adverse outcomes when compared to multi-day stay patients $(5,6)$. Studies of

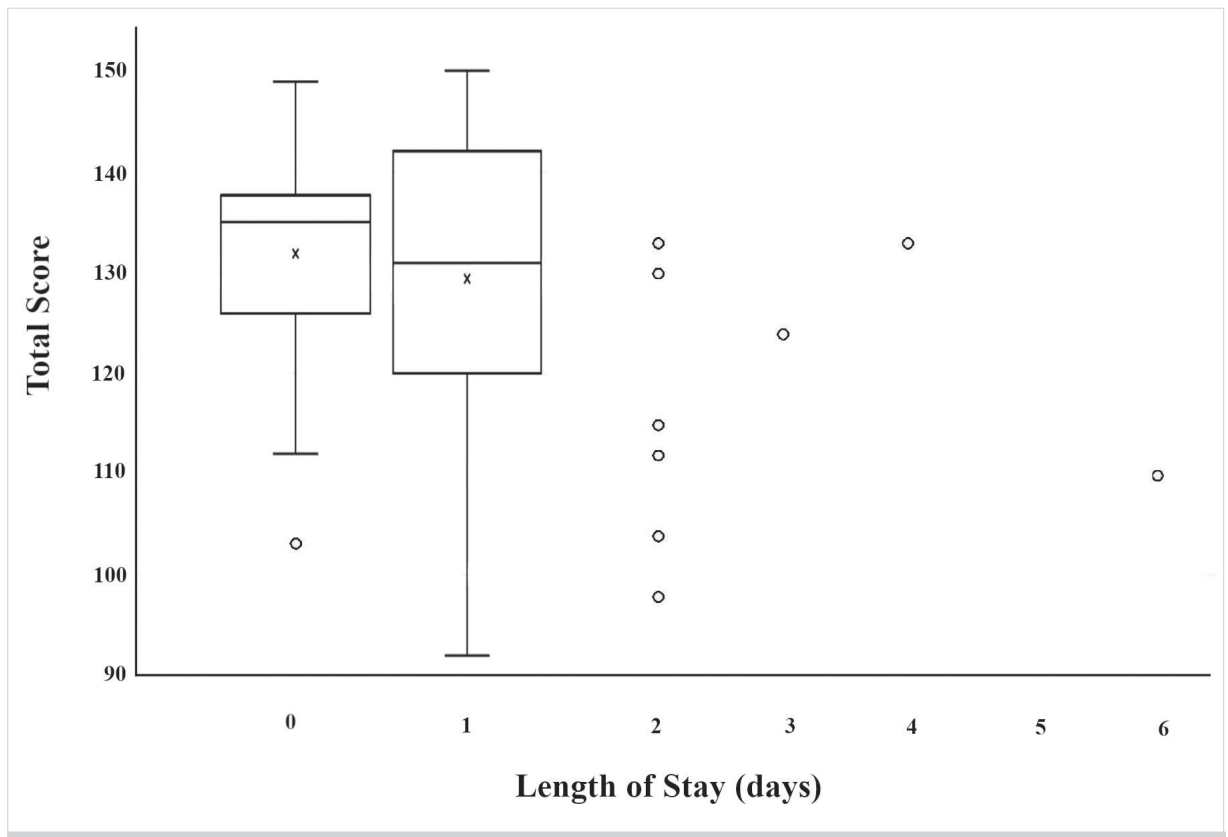

Figure 1. QoR-15 scores per length of stay. 
Table 2. Patient demographics

\begin{tabular}{|c|c|c|c|}
\hline & Day Case $(n=34)$ & Multi-Day $(n=74)$ & $\mathrm{p}$ \\
\hline Age & 44.0 & 49.1 & 0.118 \\
\hline Gender - Female & 26 & 52 & 0.335 \\
\hline Booked as Day Case & 25 & 5 & $<0.001^{*}$ \\
\hline Significant Comorbidities & 1 & 14 & $0.020^{*}$ \\
\hline $\mathrm{BMI}>30$ & 2 & 3 & \\
\hline Ischaemic Heart Disease & 0 & 4 & \\
\hline Cerebrovascular Event & 0 & 2 & \\
\hline Chronic Obstructive Pulmonary Disease & 0 & 3 & \\
\hline Peripheral Vascular Disease & 0 & 2 & \\
\hline Obstructive Sleep Apnoea & 0 & 1 & \\
\hline Other & 1 & 6 & \\
\hline Additional Procedure & 3 & 8 & 0.524 \\
\hline Umbilical Hernia Repair & 2 & 4 & \\
\hline Gastroscopy & 1 & 0 & \\
\hline Laparoscopic Bile Duct Exploration & 0 & 2 & \\
\hline Significant Adhesiolysis (>45 min) & 0 & 2 & \\
\hline AM list & 23 & 28 & $0.004^{*}$ \\
\hline Surgical Time & 73.0 & 83.9 & 0.074 \\
\hline Morbidity & 2 & 4 & 0.617 \\
\hline Clavien-Dindo 1/2 & 2 & 1 & \\
\hline Clavien-Dindo 3/4 & 0 & 3 & \\
\hline
\end{tabular}

Table 3. QoR-15 results comparing day case and multi-day patients, mean score (95\% Cl)

\begin{tabular}{|l|c|c|c|}
\hline Question & Day Case $(\mathbf{n}=\mathbf{3 4})$ & Multi-Day (n= 74) & 0.934 \\
\hline 1 & $9.4(9.0-9.8)$ & $9.4(9.1-9.7)$ & 0.577 \\
\hline 2 & $8.4(7.7-9.0)$ & $8.1(7.6-8.6)$ & 0.738 \\
\hline 3 & $8.3(7.6-8.9)$ & $8.1(7.6-8.6)$ & $0.013^{*}$ \\
\hline 5 & $7.4(6.7-8.2)$ & $5.9(5.2-6.7)$ & 0.178 \\
\hline 6 & $9.6(9.3-10.0)$ & $9.2(8.9-9.6)$ & 0.95 \\
\hline 7 & $9.9(9.8-10.0)$ & $9.9(9.8-10.0)$ & 0.855 \\
\hline 8 & $9.6(9.4-9.9)$ & $9.6(9.3-9.9)$ & 0.662 \\
\hline 9 & $6.7(5.8-7.5)$ & $6.4(5.8-7.5)$ & 0.699 \\
\hline 10 & $8.6(8.1-9.1)$ & $8.5(8.1-8.9)$ & 0.525 \\
\hline 11 & $8.4(7.9-9.0)$ & $8.6(8.3-9.0)$ & 0.946 \\
\hline 12 & $6.9(6.1-7.7)$ & $7.0(6.5-7.5)$ & 0.151 \\
\hline 13 & $9.6(9.1-10.0)$ & $9.0(8.6-9.5)$ & 0.500 \\
\hline 14 & $9.5(9.0-10.0)$ & $9.3(9.0-9.6)$ & $0.021^{*}$ \\
\hline 15 & $9.9(9.6-10.2)$ & $9.2(8.8-9.5)$ & 0.589 \\
\hline Overall Total & $9.7(6.4-10.0)$ & $9.6(9.3-9.9)$ & 0.147 \\
\hline *Indicates significance $p<0.05$ & $132.0(128.2-135.7)$ & $127.9(124.5-131.3)$ & \\
\hline & & & \\
\hline
\end{tabular}


Table 4. QoR-15 results comparing intention to treat (patients booked as day case or multi-day), mean score (95\% Cl)

\begin{tabular}{|l|c|c|c|}
\hline Question & Day Case $(\mathbf{n}=\mathbf{3 0})$ & Multi-Day (n= 78) & 0.568 \\
\hline 1 & $9.5(9.1-9.9)$ & $9.4(9.1-9.6)$ & 0.979 \\
\hline 3 & $8.2(7.3-9.1)$ & $8.2(7.7-8.7)$ & 0.21 \\
\hline 4 & $7.8(6.9-8.6)$ & $8.3(7.9-8.8)$ & 0.11 \\
\hline 5 & $7.1(6.2-8.1)$ & $6.1(5.4-6.8)$ & 0.669 \\
\hline 6 & $9.5(9.0-9.9)$ & $9.3(9.0-9.7)$ & 0.922 \\
\hline 7 & $9.9(9.7-10.1)$ & $9.9(9.8-10.1)$ & 0.898 \\
\hline 8 & $9.6(9.3-9.9)$ & $9.6(9.4-9.9)$ & 0.856 \\
\hline 9 & $6.4(5.5-7.3)$ & $6.5(5.9-7.2)$ & 0.878 \\
\hline 10 & $8.6(8.0-9.2)$ & $8.5(8.1-8.9)$ & 0.306 \\
\hline 11 & $8.3(7.6-9.0)$ & $8.7(8.4-9.0)$ & 0.642 \\
\hline 12 & $6.8(6.0-7.6)$ & $7.0(6.5-7.5)$ & 0.279 \\
\hline 13 & $9.5(9.0-10.0)$ & $9.1(8.8-9.5)$ & 0.749 \\
\hline 14 & $9.4(8.9-10.0)$ & $9.3(9.0-9.7)$ & $0.043^{*}$ \\
\hline 15 & $9.8(9.5-10.2)$ & $9.2(8.8-9.6)$ & 0.417 \\
\hline Overall Total & $9.8(9.5-10.1)$ & $9.6(9.2-9.9)$ & 0.631 \\
\hline$*$ Indicates significance $p<0.05$. & $130.2(125.9-134.5)$ & $128.8(125.6-132.0)$ & \\
\hline
\end{tabular}

Table 5. QoR-15 outcomes comparing perceived critical variables

\begin{tabular}{|c|c|c|c|}
\hline Variable & & & $\mathrm{p}$ \\
\hline Comorbidity & No $(n=93)$ & Yes $(n=15)$ & \\
\hline QoL-15 score & 129.7 & 126.3 & 0.381 \\
\hline Comorbidity \pm Day Case & Day Case $(n=1)$ & Multi-Day $(n=14)$ & \\
\hline QoL-15 score & 135.0 & 125.7 & 0.614 \\
\hline Additional Procedure & No $(n=97)$ & Yes $(n=11)$ & \\
\hline QoL-15 score & 129.2 & 129.0 & 0.962 \\
\hline Additional Procedure \pm Day Case & Day Case $(n=3)$ & Multi-Day $(\mathrm{n}=8)$ & \\
\hline QoL-15 score & 127.7 & 128.3 & 0.960 \\
\hline AM or PM list & $\operatorname{AM}(n=51)$ & $P M(n=57)$ & \\
\hline QoL-15 score & 129.4 & 129.0 & 0.881 \\
\hline AM list \pm Day Case & Day Case $(\mathrm{n}=23)$ & Multi-Day $(\mathrm{n}=28)$ & \\
\hline QoL-15 score & 130.7 & 128.3 & 0.468 \\
\hline PM list \pm Day Case & Day Case $(\mathrm{n}=11)$ & Multi-Day $(n=46)$ & \\
\hline QoL-15 score & 134.5 & 127.7 & 0.173 \\
\hline
\end{tabular}

other laparoscopic operations have found similar outcomes, particularly with laparoscopic appendicectomy, laparoscopic hysterectomy and laparoscopic hiatal surgery (9,13-16). This study was not powered to look at safety, but does suggest minimal morbidity in both groups. However, the observed higher rate of significant Clavien-Dindo 3 and 4 complications in the multi-day group was associated with the increased number of patients with serious co-morbidities and may suggest a group where it would be prudent to maintain a multi-day admission with prolonged observation (Table 2).

The counter argument is that if even only a subset of patients is able to be treated as a day case, this still provides benefits for hospital flow. A significant drive towards performing laparoscopic cholecystectomy as a day case is the potential to save on bed stay costs in the hospital setting. Although costs differ between health systems and it is difficult to directly compare 
between these, it is apparent that by reducing the number of admitted patients following surgery, the related costs from an overnight stay can be avoided $(7,8)$. In real terms, this may not always mean an empty bed for the night with savings on nursing, cleaning and medication costs, but having the ability to admit another patient and gaining the associated revenue. This cost saving feature has been investigated by various studies that all highlight the significant reduction in costs from performing laparoscopic cholecystectomy operations as day cases and using freed up resources to increase revenue in other areas $(6-8,14,17)$. This study did not evaluate the costs associated with patient admissions, but with at least equivalent results for day case patients, and a large number of patients in the multi-day group not co-morbid, there is the potential for a greater percentage of patients being treated as day procedures leading to further savings.

With the available evidence thus far suggesting that there is a cohort of patients undergoing laparoscopic cholecystectomy that is both safe to discharge on the same day, and provide an economic benefit to the hospital, it is relevant in this context to consider patient satisfaction. Post-operative pain is only one aspect of this, and quality of recovery measurement tools have been developed to encompass the multiple factors that are of importance to a patient recovering from an operation $(10,12)$. QoR-15 questionnaire was used by this study as a well-established tool for this purpose, and demonstrated an observed (but not statistically significant) increase in scores in the day case group. It may not be a surprise that day case patients recorded a significantly better score for quality of sleep with potential interruptions including overnight interruptions for nursing observations or loud/snoring nearby patients. Interestingly, day case patients also recorded a better score for feelings of worry or anxiety, contrary to the thought that having a nurse nearby may moderate these thoughts. These results are echoed in the limited literature published on patient satisfaction with day case laparoscopic cholecystectomy which demonstrates no significant difference in their patient recovery symptom scores (18).

These studies highlight the need for selection of a cohort of patients to whom day case surgery is offered. Common patient factors that could inhibit offering surgery to patients as a day case may include an ASA score of 3 or greater, multiple comorbidities, uncontrolled pain, or supplemental oxygen requirement (19). Most of these factors are known in the lead up to surgery and can therefore be used to direct bookings between day cases or overnight admissions for patients, however ideally pre-operative education of patients regarding day case surgery should be delivered by the surgeon in the outpatient clinic $(20,21)$. The results of this study demonstrate no difference in QoL-15 scores in patients with significant co-morbidities, however details, such as chronic pain, were not recorded and there are likely to be particular features in some individuals that necessitate overnight care. Other studies analysing the safety of day case laparoscopic surgeries also state that stringent selection of patients allows for maximised safety $(9,11,22-24)$. These studies also confirm supports at home as critical for same day discharge after laparoscopic surgery. This study shows that there is no difference in whether the operation is in the morning or afternoon, with an observed but non-significant trend towards improved scores in PM list patients. However, the actual time of operation was not recorded and there may be differences between patients operated on first in the afternoon and patients at the end of the afternoon list, as well as recovery staffing issues.

This study is limited by a relatively small study size, and thus there exists the possibility of a type 2 error. However, the trend is towards a benefit with day case surgery, and further numbers may confirm this approach as significantly better in terms of quality of recovery. A randomised trial will likely be difficult to perform in this setting, with ethical difficulties in keeping suitable day case patients in hospital overnight.

\section{CONCLUSION}

Day case laparoscopic cholecystectomy is both a safe and feasible alternative to admission for appropriate patients, and there are significant cost reductions involved with such management. It appears that a combination of traditional management, surgeon's preference and patient's preference is the driving force behind the decision for overnight stay. This study shows that from the patients' perspective, their quality of recovery is just as good, if not better, when managed as a day case rather than a multi-day case. This gives added weight to the development of recommendations that the majority of laparoscopic cholecystectomy operations could be performed as day cases.

Ethics Committee Approval: This study approval was obtained from Northern Health Hospital Human Research Ethics Committee (Decision no: ALR 16.2018, Date: 20.06.2018).

Peer-review: Externally peer-reviewed.

Author Contributions: Author Contributions: Concept - D.L., D.B., R.H.; Design - D.L., R.H.; Supervision - D.B., R.H.; Data Collection and/or Processing - D.B., B.A.; Analysis and/or Interpretation - M.C., B.A., R.H.; Literature Search - M.C., D.B., R.H.; Writing Manuscript - M.C.; Critical Reviews - All of authors.

Conflict of Interest: The authors have no conflicts of interest to declare.

Financial Disclosure: The authors declared that this study has received no financial support.

\section{REFERENCES}

1. Watters D. Clinical Variation: Procedure in profile: Laparoscopic cholecystectomy. Surgical News 2016; 17: 38. Available from: https:// umbraco.surgeons.org/media/1415/art-2016-04-01-surgical-newsapril-for-web.pdf (Accessed date: 16th of November 20). [CrossRef] 
2. Briggs CD, Irving GB, Mann CD, Cresswell A, Englert L, Peterson M, et al. Introduction of a day-case laparoscopic cholecystectomy service in the UK: a critical analysis of factors influencing same-day discharge and contact with primary care providers. Ann R Coll Surg Engl 2009; 91(7): 583-90. [CrossRef]

3. Ismail S, Ahmed A, Hoda MQ, Sohaib M, Rehman Zia-Ur. Prospective survey to study factors which could influence same-day discharge after elective laparoscopic cholecystectomy in a tertiary care hospital of a developing country. Updates Surg 2016; 68(4): 387-93. [CrossRef]

4. Ahn Y, Woods J, Connor S. A systematic review of interventions to facilitate ambulatory laparoscopic cholecystectomy. HPB (Oxford) 2011; 13(10): 677-86. [CrossRef]

5. Lau H, Brooks DC. Contemporary outcomes of ambulatory laparoscopic cholecystectomy in a major teaching hospital. World J Surg 2002; 26(9): 1117-21. [CrossRef]

6. Rosen MJ, Malm JA, TarnoffM, Zuccala K, Ponsky JL. Cost-effectiveness of ambulatory laparoscopic cholecystectomy. Surg Laparosc Endosc Percutan Tech 2001; 11(3): 182-4. [CrossRef]

7. Jain PK, Hayden JD, Sedman PC, Royston CMS, O'Boyle CJ. A prospective study of ambulatory laparoscopic cholecystectomy: Training economic, and patient benefits. Surg Endosc 2005; 19(8): 1082-5. [CrossRef]

8. Manzia TM, Quaranta C, Filingeri V, Toti L, Anselmo A, Tariciotti L, et al. Feasibility and cost effectiveness of ambulatory laparoscopic cholecystectomy. A retrospective cohort study. Ann Med Surg (Lond) 2020; 55: 56-61. [CrossRef]

9. Lassen PD, Moeller-Larsen H, DE Nully Pia. Same-day discharge after laparoscopic hysterectomy. Acta Obstet Gynecol Scand 2012: 91(11): 1339-41. [CrossRef]

10. Stark PA, Myles PS, Burke JA. Development and psychometric evaluation of a postoperative quality of recovery score: the QoR-15. Anesthesiology 2013; 118(6): 1332-40. [CrossRef]

11. Trejo-Avila ME, Romero-Loera S, Cardenas-Lailson E, Blas-Franco M, Delano-Alonso R, Valenzuela-Salazar C, et al. Enhanced recovery after surgery protocol allows ambulatory laparoscopic appendectomy in uncomplicated acute appendicitis: A prospective, randomized trial. Surg Endosc 2019; 33(2): 429-36. [CrossRef]

12. Chazapis M, Walker EMK, Rooms MA, Kamming D, Moonesinghe SR. Measuring quality of recovery-15 after day case surgery. $\mathrm{Br} J$ Anaesth 2016; 116(2): 241-8. [CrossRef]
13. Cross W, Chandru Kowdley G. Laparoscopic appendectomy for acute appendicitis: A safe same-day surgery procedure? Am Surg 2013; 79(8): 802-5. [CrossRef]

14. Dubois L, Vogt KN, Davies W, Schlachta CM. Impact of an outpatient appendectomy protocol on clinical outcomes and cost: A case-control study. J Am Coll Surg 2010; 211(6): 731-7. [CrossRef]

15. Frazee RC, Abernathy SW, Davis M, Hendricks JC, Isbell TV, Regner JL, et al. Outpatient laparoscopic appendectomy should be the standard of care for uncomplicated appendicitis. J Trauma Acute Care Surg 2014; 76(1): 79-82. [CrossRef]

16. Molina JC, Misariu AM, Nicolau I, Spicer J, Mulder D, Ferri LE, et al. Same day discharge for benign laparoscopic hiatal surgery: A feasibility analysis. Surg Endosc 2018; 32(2): 937-44. [CrossRef]

17. Narain PK, De Maria EJ. Initial results of a prospective trial of outpatient laparoscopic cholecystectomy. Surg Endosc 1997; 11(11): 1091-4. [CrossRef]

18. Young J, O'Connell B. Recovery following laparoscopic cholecystectomy in either a 23 hour or an 8 hour facility. J Qual Clin Pract 2001; 21(1-2): 2-7. [CrossRef]

19. Brenner P, Kautz DD. Postoperative care of patients undergoing same-day laparoscopic cholecystectomy. AORN J 2015; 102(1): 16-29. [CrossRef]

20. Kruzik N. Benefits of preoperative education for adult elective surgery patients. AORN J 2009; 90(3): 381-7. [CrossRef]

21. de Aguilar-Nascimento JE, Leal FS, Dantas DCS, Anabuki NT, de Souza AMC, E Lima VPS, et al. Preoperative education in cholecystectomy in the context of a multimodal protocol of perioperative care: $A$ randomized, controlled trial. World J Surg 2014; 38(2): 357-62. [CrossRef]

22. Inaba CS, Koh CY, Sujatha-Bhaskar S, Pejcinovska M, Nguyen NT. How safe is same-day discharge after laparoscopic sleeve gastrectomy? Surg Obes Relat Dis 2018; 14(10): 1448-53. [CrossRef]

23. Lalezari S, Musielak MC, Broun LA, Curry TW. Laparoscopic sleeve gastrectomy as a viable option for an ambulatory surgical procedure: Our 52-month experience. Surg Obes Relat Dis 2018; 14(6): 748-50. [CrossRef]

24. Surve A, Cottam D, Zaveri H, Cottam A, Belnap LeGrand, Richards C, et al. Does the future of laparoscopic sleeve gastrectomy lie in the outpatient surgery center? A retrospective study of the safety of 3162 outpatient sleeve gastrectomies. Surg Obes Relat Dis 2018; 14(10): 1442-7. [CrossRef] 


\title{
ORIJINAL ÇALIŞMA-ÖZET
}

Turk J Surg 2021; 37 (4): 355-362

\section{Elektif laparoskopik kolesistektomi uygulanan günübirlik ve uzun yatışlı hastaların iyileşme kalitesinin değerlendirmesi}

\author{
Matthew Campbell ${ }^{1}$, Daniel $\mathrm{Ng}^{1}$, Batool Albatat ${ }^{1}$, Darren Lowen ${ }^{2}$, David Bird ${ }^{1}$, Russell Hodgson ${ }^{1}$ \\ ${ }^{1}$ Northern Health Hastanesi, Genel Cerrahi Kliniği, Epping, Avustralya \\ ${ }^{2}$ Northern Health Hastanesi, Anestezi Kliniği, Epping, Avustralya
}

\section{ÖZET}

Giriş ve Amaç: Birçok laparoskopik kolesistektomi operasyonu gecelik yatış ile uygulanmaktadır. Güncel araştırmalar, laparoskopik kolesistektomi operasyonunun günübirlik şekilde yapılmasının güvenilir ve uygulanabilir olduğunu ortaya koymuştur. Hasta odaklı sonuçlar ise daha az anlaşılmıştır.

Gereç ve Yöntem: Avustralya'nın Melbourne şehrinde tek bir merkezde elektif laparoskopik kolesistektomi geçiren hastalar, operasyon sonrası 24. saatte 15 soruluk Quality of Recovery (QoR-15) (lyileşme Kalitesi) anketi kullanılarak incelendi. Günübirlik kalan ve uzun yatışlı hastalar arasında karşılaştırma yapıldı.

Bulgular: Otuz dördü günübirlik, 74'ü uzun yatışlı hastalar olmak üzere toplam 108 hasta çalışmaya dahil edildi. Yaş, cinsiyet ve postoperative morbidite açısından hasta grupları arasında bir fark yoktu. Uzun yatışı hasta grubunda komorbiditesi olan hastalar daha yüksek orandaydı (p-değeri= 0,03). Günübirlik grupta daha yüksek bir skor trendi olsa da toplam QoR-15 skoru açısından iki grup arasında anlamlı bir fark bulunmadı (132.0 vs 127,9, p=0,147). QoR-15, bireysel sorulara verilen cevaplar günübirlik olguların daha iyi uyku kalitesine sahip olduğunu ve daha düşük endişe ve tedirginlik hissi yaşadığını ortaya koydu. Farkıııklar, hasta gruplarının kayıt edildikleri şekilde (tedavi niyeti) karşılaştırılmaları sonucunda daraldı. Uzun yatışı olsa anlamlı şekilde daha yüksek skor alacak herhangi bir alt grup yoktu.

Sonuç: Günübirlik laparoskopik kolesistektomi sonrasında iyileşme kalitesinin uzun yatışlı hastalara kıyasla daha iyi olmasa da bir o kadar iyi olduğu bulundu. Günübirlik laparoskopik kolesistektomi hem güvenli hem de uzun yatışa kıyasla daha ekonomiktir. Bu durum, laparoskopik kolesistektomi operasyonlarının çoğunluğunu günübirlik vakalar olacak şekilde uygulanmasını öneren mevcut tavsiyelere destek çıkmaktadır.

Anahtar Kelimeler: Laparoskopik kolesistektomi, safra kesesi taşı, günübirlik hasta, iyileşme kalitesi

Doi: $10.47717 /$ turkjsurg.2021.5451 